\title{
Mechanism of Discerning Similarities in Psychiatric Diagnoses
}

\author{
Haim Eshach \\ Ben Gurion University of the Negev, Beer Sheva, Israel \\ Email: heshach@gmail.com
}

Received April 23 ${ }^{\text {rd }}$, 2013; revised May 23 ${ }^{\text {rd }}$, 2013; accepted May 31 ${ }^{\text {st }}, 2013$

\begin{abstract}
Copyright (C) 2013 Haim Eshach. This is an open access article distributed under the Creative Commons Attribution License, which permits unrestricted use, distribution, and reproduction in any medium, provided the original work is properly cited.
\end{abstract}

\begin{abstract}
Psychiatrists use similarities to make diagnoses in situations where rules are insufficient. The purpose of this study was to examine the criteria psychiatrists use to determine similarity between cases of personality disorder. Psychiatrists were provided with cases and were interviewed according to Kelly's method. Cognitive science theories were used to explain the criteria identified. Results indicated that similarity decisions include idiosyncratic criteria. These results add to the current understanding of medical problem-solving processes and have implications for medical education.
\end{abstract}

Keywords: Similarity; Psychiatric Diagnoses; Medical Education

\section{Introduction}

Clinical reasoning, a highly complex phenomenon (Higgs \& Jones, 1995), is defined as the thinking processes occurring while dealing with a clinical case (Boshuizen \& Schmidt, 1995). The problems that patients present can be confusing and contradictory, characterized by imperfect, inconsistent, or even inaccurate information (Kassirer \& Kopelman, 1991; Eshach \& Bitterman, 2002). In addition, medical problems are often poorly defined (Barrows \& Feltovich, 1987). Not only is much irrelevant information present, but relevant information about the case is often missing and does not become apparent until after problem solving has begun (Voss \& Post, 1988). In such cases, it is difficult to specify the state from which one can start, to identify the medical interventions that might be applicable, or even to recognize when the goal has been achieved. In other words, many medical problems are ill-defined. Moreover, in many situations, the deterministic mechanisms that account for the medical problems are not completely understood (Williams, 1992). In other words, many medical domains are "ill-domain theories". Despite the uncertainty and variation that characterize physicians' work they have to diagnose and treat such illnesses. In order to do this, physicians use different types of reasoning e.g. rule-based reasoning and similarity-based reasoning. In the following paragraphs I first explain why personality disorder realm was chosen for the purpose of this study. Secondly I explain why rule-based reasoning cannot alone explain the variety of medical decision making processes. Third, I argue that similarity decisions may be effective to solve ill-defined problems in ill domains. I then suggest to study the factors according which similarities are made.

\section{Personality Disorders as the Focus of the Study}

The etiology and pathogenesis of most personality disorders are not known; psychiatrists therefore tend to resort to phenomenological, descriptive criteria in the diagnosis of these conditions. Many of the definitions provided in the Diagnostic and Statistical Manual of Mental Disorders (DSM-IV) (American Psychiatric Association, 1994) are set up in a format whereby an individual must have a subset of several features in order to be diagnosed. Thus, for the nine DSM-IV diagnostic features of borderline personality, for instance, at least five of which are required for diagnosis, there are 256 different criteria combinations that can result in this diagnosis (Morey, 1998). In addition, the study of personality disorder leads into areas in which the distinction between health and sickness is inherently ambiguous and is potentially biased by societal norms and personal values. To a large extent, whether persons are considered to have a personality disorder depends on whether their personality traits are noxious to the society in which they live and, in particular, to the persons with whom they most frequently interact (Kaplan \& Sadock, 1996). This means that formal diagnostic systems such as the DSM-IV, which define rules to categorize discrete pathological entities, are not sufficient and cannot always lead to the diagnosis of the personality disorder. Despite the uncertainty and variation that characterize personality disorders, psychiatrists have to diagnose and treat them. It is my assumption that perceiving similarities, an ability that is one of the most fundamental aspects of human cognition (Vosniadou \& Ortony, 1989), is used by psychiatrists in the diagnostic and treating of personality disorders.

\section{Domain Rule-Based Reasoning}

In order to better understand this phenomenon one should first distinguish between domain rule-based reasoning (RBR) and the use of a rule or rules in problem solving. The former is identified as the process of drawing conclusions by chaining together generalized rules, starting from scratch (Leake, 1996). The latter, on the other hand does not require starting from scratch nor does it require chaining together rules. For the purpose of this study I will focus on RBR processes. RBR models are rooted in the philosophical belief that humans are rational 
beings and that the laws of logic are the laws of thoughts (Eysenck \& Keane, 1995). According to Kolodner (1993), although some rules are very specific, the goal is to formulate rules that are generally applicable. An important advantage of rules is the economy of storage they allow. But general knowledge has the problem of applicability (Mostow, 1983), i.e., the bringing of some general piece of knowledge to a particular situation. When rules are expressed too abstractly, the terms tend to be unintelligible to the novice and to mean a variety of specific things to the expert. Also, in ill-defined domains, the rules do not encompass all the situations they are asked or assumed to cover, admit tacit exceptions, or can be contradicted and annulled by other rules (Rissland \& Skalak, 1991).

Limited mental capacity is another reason why RBR alone cannot explain the human problem-solving processes. RBR, which requires that the problem solver take into account all the domain rules, is not capable of doing that in real-life situations (BarOn, 1993), as the number of rules required for solving a problem may be unmanageably large (Leake, 1996). Similarity based reasoning offers an attractive way out of these difficulties. Rather than having to patch up abstract rules with endless sub-rules, according to similarity-based models of reasoning, problem solving depend, especially while working in ill-domains theories and ill problems, on the ability to identify the most relevant bodies of knowledge that already exist in memory so that this knowledge can be used as a starting point for encounter the novel situation. I do not focus on a particular model such as the prototype models, the exampler models, connectionist models and the probabilistic models, but rather relate to the similarities underlying all these kinds of models.

\section{Similarity}

Rumelhart (1989) claims that most everyday reasoning probably involves assimilating the novel problem to other situations in which the solutions are known-that is, reasoning by similarity. He further suggests that the reason for the important role of reasoning by similarity is the essential human ability for pattern matching. "We seem to be able to 'settle' quickly on interpretation of an input pattern. This is an ability that is central to perceiving, remembering, comprehending, and reasoning by similarity. Our ability to pattern-much is probably not something that sets humans apart from other animals but is probably the essential component to most cognitive behavior" (Rumelhart, 1989: p. 300). Support for similarity processes can be found in cognitive neurosciences research. This indicates that different neural circuits are involved when people categorize items on the basis of a rule, as compared with when they categorize the same items on the basis of similarity (Kolodny, 1994).

The term "similarity", which typically refers to the outcome of comparison among entities, can be regarded as a form of judgment-what people say when asked to compare different entities (Sloman \& Rips, 1998). Goodman (1972) argues that claiming that two things are similar is uninformative until we specify in what respect they are similar. According to Goldstone (1994) people do not usually compare objects only in a single respect such as "size" but along multiple dimensions such as size, color, shape, etc. Kelly (1955a) claims that two things are "similar", "alike", or "identical” obviously means that they are alike in some particular way or ways, but, of course, never in every way. Their alikeness makes no sense unless it also serves to distinguish them from certain other things. Thus, according to Kelly, likeness always implies a difference. At the same time, the way in which two things are different must, if it is to make any sense at all, be the way in which at least one of them is like a third thing.

\section{Aims}

This study focused on understanding the process of how professionals find similarities between cases. The following questions are therefore addressed:

1) What are the differences between the various diagnoses given by psychiatrists to given cases?

2) What are the criteria that psychiatrists use to decide on similarities between cases?

\section{Method}

\section{Participants}

Nine psychiatrists at different levels of medical experience were chosen for this study.

Participant 1: 20 years' experience; Participant 2: 6 years' experience; Participant 3: 7 years' experience; Participant 4: 10 years' experience; Participant 5: 5 years' experience; Participant 6: 2 years' experience; Participant 7: 4 years' experience; Participant 8: 5 years' experience; Participant 9: 5 years' experience.

\section{Procedure}

1) Nine patients diagnosed as suffering from personality disorders according to DSM-IV criteria who agreed to participate in the study were identified. The following list describes the diagnosis given by the department in which the patients were treated:

a) Narcissistic personality disorder with dependent traits;

b) Borderline personality disorder with narcissistic traits;

c) Narcissistic personality disorder;

d) Borderline personality disorder;

e) Narcissistic personality disorder;

f) Dependent personality disorder;

g) Narcissistic personality with obsessive traits;

h) Obsessive-compulsive disorder;

i) Borderline personality with narcissistic traits.

A psychiatrist who was very familiar with all the cases conducted an introductory interview with each one of the patients. This enabled him to extract the maximum and most pertinent information from each case. The interviews lasted between 20 and 25 minutes. The interviews were videotaped and transcribed. Transcripts of each interview were used as cases introduced to the participants.

2) The transcripts of the nine cases were presented to each of the participants, all of whom were unfamiliar with the nine patients. The participants were each instructed to do the following :

a) Diagnose each case. The participants were asked to think aloud while diagnosing the cases. These sessions were taperecorded, and verbatim transcripts were produced.

b) Group cases according to important similarities of their own choice.

${ }^{1}$ This idea is the basis for Kelly's (1955) repertory test, from which we have drawn the interviews described in the method for the current research. 
c) Consider predefined sets of three cases and describe how two of the three cases are alike and how they are different from the third; in other words, to decide on a criterion for the similarity between two cases among the three presented in the set.

d) Subsequently, to indicate which of the remaining six cases matched the chosen criteria.

For c) and d), Table 1 was used as a template for the interview.

The author interviewed each participant, each interview lasting between 5 and 6 hours. Since the interviews were so long, they were divided into two parts of between 2.5 and 3 hours each, conducted on two successive days. In this way the participants remembered the cases, and it took very little time for them to go over the cases again. After piloting the interview method, it became clear that 14 sets were optimum for interview acceptability by the participants.

This method required the identification of the two most similar cases of a set of three and enabled us to identify the variety of criteria used to decide on similarities between cases. For instance, when participant 4 was introduced to set 4 (cases 2, 5, and 8), she identified cases 2 and 8 as similar. She explained, "In both cases they try to solve an internal conflict. The crisis starts early in life. Case 5 is not trying to solve an internal conflict”. When the participant was presented with set 5 , she again identified cases 2 and 8 as similar. She explained that both cases had "organized life, while case 3 had chaotic life". For the same pair of cases she used different criteria.

\section{Analysis}

The interview audiotapes were transcribed verbatim, and inductive analysis, in which patterns, themes, and categories of

Table 1.

Interview template.

\begin{tabular}{cccccc}
\hline $\begin{array}{c}\text { Set } \\
\text { number }\end{array}$ & $\begin{array}{c}\text { Set of three } \\
\text { cases }^{\mathrm{a}}\end{array}$ & $\begin{array}{c}\text { Similar }^{\mathrm{c}} \text { cases }^{\mathrm{b}} \\
2\end{array}$ Explanation $^{\mathrm{c}}$ & $\begin{array}{c}\text { Other similar } \\
\text { cases }^{\mathrm{d}}\end{array}$ \\
\hline 1 & 2 & 3 & 4 & & \\
3 & 3 & 5 & 7 & \\
4 & 2 & 5 & 8 \\
5 & 2 & 3 & 8 \\
6 & 1 & 6 & 8 \\
7 & 1 & 3 & 5 \\
8 & 4 & 5 & 9 \\
9 & 2 & 4 & 5 \\
10 & 2 & 6 & 8 \\
11 & 5 & 7 & 9 \\
12 & 2 & 4 & 9 \\
13 & 4 & 5 & 8 \\
14 & 3 & 7 & 9
\end{tabular}

Note: ${ }^{\mathrm{a} P r e d e f i n e d ~ s e t s ~ o f ~ t h r e e ~ c a s e s ~ e a c h . ~}{ }^{\mathrm{b}}$ Those two cases that the participant identified as similar. 'Reasons that the participant gave in answer to "in what respect are the cases similar?" "Those cases of the six remaining that the participant identified as similar to the earlier two cases already chosen for their similarity. analysis derived from the data (Patton, 1990), was employed. The analysis process contained the following:

All the transcripts were repeatedly read to formulate tentative understanding.

a) In subsequent readings, an attempt to find confirmation or disconfirmation to the tentative understanding of the phenomena on the tape was made.

b) Through this process of constant comparison (Strauss, 1987), initial categories for the differences between the diagnoses were established.

c) In the same manner, criteria used to decide similarities were identified, and initial categories for the criteria were recognized.

d) The data were repeatedly reread, and the initial categories were revised as a result of several rounds of discussion verification methodology (Strauss, 1987).

e) This sharing and critiquing also assisted in the process of progressive subjectivity (Guba \& Lincoln, 1989).

\section{Results and Discussion}

\section{Results Regarding the Diagnoses}

1) Differences between the diagnoses given by the nine participants were found. Table 2 summarizes the diagnoses that were given to each case by the participants.

2) Four classes of difference were identified. See Table 3.

3) The data indicated that the participants focused on deferent details in each case. The following citations of three participants (2, 6, and 9) while diagnosing the same case (6) demonstrate this phenomenon:

Participant 2: "He [the patient] describes his life through his functional ability and less through interrelationships with others. Despite not being uncomfortable around people, he was never close to them. There is a personality disorder on the basis of creating relationships with other people ... In this case schizoid personality disorder seems to me as the one he suffers from ..."

Participant 9: "The more reasonable possibility seems to me that he wants the insurance money. He does not describe psychiatric details, but things that anyone can describe. He continues to describe details from the accident and what happened due to the accident. He doesn't cooperate on discussing details after the accident. He does not remember how he was as a high school student, which indicates memory disorder, which seems unreasonable in this case."

Participant 6: "His work provided him with high self-esteem. Everyone related to him in a special way; they liked him. He was always the best. In this case I would say that he is a narcissistic personality."

Each participant focused on other details in the same case. Participant 2 focused on the nature of the interpersonal relations of the patient (case). Participant 9 focused on the accident details. Participant 6 focused on details describing the patient's workplace. This might be one explanation for the differences between the diagnoses given by the participants.

\section{Results Regarding Criteria Used to Decide on Similarity}

1) Four categories of the criteria used by the participants to decide similarities between cases were identified:

a) Diagnosis as it appears in the literature (e.g., "cases 2 and 3 are similar because they are both narcissists”). Narcissist is a 
Table 2.

Diagnosis given to each case by the participants.

\begin{tabular}{|c|c|c|c|c|c|c|c|c|c|}
\hline & Case 1 & Case 2 & Case 3 & Case 4 & Case 5 & Case 6 & Case 7 & Case 8 & Case 9 \\
\hline 1 & $\begin{array}{l}\text { Narcissistic } \\
\text { personality } \\
\text { with } \\
\text { dependent } \\
\text { traits }\end{array}$ & $\begin{array}{c}\text { Borderline } \\
\text { personality with } \\
\text { narcissistic traits }\end{array}$ & $\begin{array}{l}\text { Narcissistic } \\
\text { personality }\end{array}$ & $\begin{array}{l}\text { Borderline } \\
\text { personality }\end{array}$ & $\begin{array}{l}\text { Narcissistic } \\
\text { personality }\end{array}$ & $\begin{array}{l}\text { Dependent } \\
\text { traits }\end{array}$ & $\begin{array}{c}\text { Narcissistic } \\
\text { personality and } \\
\text { obsessive traits }\end{array}$ & $\begin{array}{l}\text { Compulsive } \\
\text { personality }\end{array}$ & $\begin{array}{c}\text { Borderline } \\
\text { personality and } \\
\text { narcissistic } \\
\text { personality }\end{array}$ \\
\hline 2 & $\begin{array}{l}\text { Narcissistic } \\
\text { traits with } \\
\text { dependent } \\
\text { traits }\end{array}$ & $\begin{array}{l}\text { Narcissistic } \\
\text { personality }\end{array}$ & $\begin{array}{c}\text { Borderline } \\
\text { personality } \\
\text { and } \\
\text { narcissistic } \\
\text { personality }\end{array}$ & $\begin{array}{l}\text { Borderline } \\
\text { personality } \\
\text { with } \\
\text { narcissistic } \\
\text { traits }\end{array}$ & $\begin{array}{l}\text { Narcissistic } \\
\text { personality }\end{array}$ & Schizoid & $\begin{array}{l}\text { Narcissistic per- } \\
\text { sonality, obsessive } \\
\text { traits, and de- } \\
\text { pendent traits }\end{array}$ & $\begin{array}{l}\text { Compulsive } \\
\text { personality }\end{array}$ & $\begin{array}{c}\text { Borderline } \\
\text { personality and } \\
\text { narcissistic } \\
\text { personality }\end{array}$ \\
\hline 3 & $\begin{array}{l}\text { Narcissistic } \\
\text { personality } \\
\text { with } \\
\text { dependent } \\
\text { traits }\end{array}$ & $\begin{array}{c}\text { Borderline } \\
\text { personality with } \\
\text { narcissistic traits }\end{array}$ & $\begin{array}{c}\text { Borderline } \\
\text { personality } \\
\text { with } \\
\text { histrionic } \\
\text { traits and } \\
\text { dependent } \\
\text { traits }\end{array}$ & $\begin{array}{l}\text { Borderline } \\
\text { personality }\end{array}$ & $\begin{array}{l}\text { Narcissistic } \\
\text { personality }\end{array}$ & $\begin{array}{l}\text { Dependent } \\
\text { personality }\end{array}$ & $\begin{array}{l}\text { Narcissistic } \\
\text { personality }\end{array}$ & $\begin{array}{l}\text { Compulsive } \\
\text { personality }\end{array}$ & $\begin{array}{c}\text { Borderline } \\
\text { personality and } \\
\text { histrionic } \\
\text { personality }\end{array}$ \\
\hline 4 & $\begin{array}{l}\text { Narcissistic } \\
\text { traits with } \\
\text { dependent } \\
\text { traits }\end{array}$ & $\begin{array}{l}\text { No personality } \\
\text { disorder }\end{array}$ & $\begin{array}{c}\text { No } \\
\text { personality } \\
\text { disorder }\end{array}$ & $\begin{array}{l}\text { Borderline } \\
\text { personality } \\
\text { with } \\
\text { obsessive } \\
\text { traits }\end{array}$ & $\begin{array}{c}\text { No } \\
\text { personality } \\
\text { disorder }\end{array}$ & $\begin{array}{c}\text { No } \\
\text { personality } \\
\text { disorder }\end{array}$ & $\begin{array}{l}\text { No personality } \\
\text { disorder }\end{array}$ & $\begin{array}{l}\text { Compulsive } \\
\text { personality }\end{array}$ & $\begin{array}{c}\text { Borderline } \\
\text { personality and } \\
\text { narcissistic } \\
\text { personality }\end{array}$ \\
\hline 5 & $\begin{array}{l}\text { Narcissistic } \\
\text { traits with } \\
\text { dependent } \\
\text { personality }\end{array}$ & $\begin{array}{l}\text { Narcissistic } \\
\text { personality }\end{array}$ & $\begin{array}{l}\text { Narcissistic } \\
\text { personality }\end{array}$ & $\begin{array}{l}\text { Borderline } \\
\text { personality }\end{array}$ & $\begin{array}{c}\text { Obsessive } \\
\text { personality and } \\
\text { narcissistic traits }\end{array}$ & $\begin{array}{c}\text { No } \\
\text { personality } \\
\text { disorder }\end{array}$ & $\begin{array}{l}\text { Narcissistic } \\
\text { personality, } \\
\text { obsessive } \\
\text { personality, and } \\
\text { dependent } \\
\text { personality }\end{array}$ & $\begin{array}{l}\text { Compulsive } \\
\text { personality }\end{array}$ & $\begin{array}{c}\text { Narcissistic } \\
\text { personality and } \\
\text { histrionic } \\
\text { personality }\end{array}$ \\
\hline 6 & $\begin{array}{l}\text { Dependent } \\
\text { personality } \\
\text { with } \\
\text { histrionic } \\
\text { traits }\end{array}$ & $\begin{array}{c}\text { Borderline } \\
\text { personality with } \\
\text { narcissistic traits }\end{array}$ & $\begin{array}{l}\text { Narcissistic } \\
\text { personality }\end{array}$ & $\begin{array}{l}\text { Borderline } \\
\text { personality }\end{array}$ & $\begin{array}{l}\text { Narcissistic } \\
\text { personality and } \\
\text { obsessive } \\
\text { personality }\end{array}$ & $\begin{array}{l}\text { Narcissistic } \\
\text { personality }\end{array}$ & $\begin{array}{l}\text { Narcissistic } \\
\text { personality, } \\
\text { obsessive traits, } \\
\text { and histrionic } \\
\text { traits }\end{array}$ & $\begin{array}{l}\text { Compulsive } \\
\text { personality } \\
\text { with paranoid } \\
\text { traits }\end{array}$ & $\begin{array}{c}\text { Borderline } \\
\text { personality and } \\
\text { histrionic } \\
\text { personality }\end{array}$ \\
\hline 7 & $\begin{array}{l}\text { Histrionic } \\
\text { personality } \\
\text { with } \\
\text { dependent } \\
\text { traits }\end{array}$ & $\begin{array}{l}\text { Borderline } \\
\text { personality }\end{array}$ & $\begin{array}{l}\text { Histrionic } \\
\text { traits and } \\
\text { borderline } \\
\text { traits }\end{array}$ & $\begin{array}{l}\text { Borderline } \\
\text { personality } \\
\text { with } \\
\text { obsessive } \\
\text { traits }\end{array}$ & $\begin{array}{c}\text { No } \\
\text { personality } \\
\text { disorder }\end{array}$ & $\begin{array}{l}\text { Dependent } \\
\text { personality }\end{array}$ & $\begin{array}{l}\text { Narcissistic } \\
\text { personality }\end{array}$ & $\begin{array}{l}\text { Narcissistic } \\
\text { personality }\end{array}$ & $\begin{array}{c}\text { Borderline } \\
\text { personality and } \\
\text { histrionic } \\
\text { personality }\end{array}$ \\
\hline 8 & $\begin{array}{l}\text { Narcissistic } \\
\text { personality } \\
\text { and } \\
\text { dependent } \\
\text { personality }\end{array}$ & $\begin{array}{l}\text { Borderline } \\
\text { personality and } \\
\text { narcissistic } \\
\text { personality }\end{array}$ & $\begin{array}{c}\text { No } \\
\text { personality } \\
\text { disorder }\end{array}$ & $\begin{array}{l}\text { Borderline } \\
\text { personality } \\
\text { with } \\
\text { obsessive } \\
\text { traits }\end{array}$ & $\begin{array}{c}\text { No } \\
\text { personality } \\
\text { disorder }\end{array}$ & $\begin{array}{c}\text { No } \\
\text { personality } \\
\text { disorder }\end{array}$ & Narcissistic traits & $\begin{array}{l}\text { Compulsive } \\
\text { Personality }\end{array}$ & $\begin{array}{l}\text { Narcissistic } \\
\text { personality, } \\
\text { histrionic } \\
\text { ersonality, and } \\
\text { borderline traits }\end{array}$ \\
\hline 9 & $\begin{array}{l}\text { Narcissistic } \\
\text { traits with } \\
\text { dependence } \\
\text { personality }\end{array}$ & $\begin{array}{l}\text { No personality } \\
\text { disorder }\end{array}$ & $\begin{array}{l}\text { Borderline } \\
\text { personality }\end{array}$ & $\begin{array}{l}\text { Borderline } \\
\text { personality }\end{array}$ & $\begin{array}{l}\text { Narcissistic } \\
\text { personality }\end{array}$ & $\begin{array}{l}\text { No } \\
\text { personality } \\
\text { disorder }\end{array}$ & $\begin{array}{l}\text { Narcissistic } \\
\text { personality }\end{array}$ & $\begin{array}{l}\text { Compulsive } \\
\text { Personality }\end{array}$ & Histrionic traits \\
\hline
\end{tabular}

personality disorder that can be found in the literature.

b) Clusters of disorders (e.g., "cases 2 and 5 are similar because they present the same cluster, while case 8 belongs to a different cluster").

c) Severity of the personality disorder (e.g., "cases 2 and 4 are more serious cases of personality disorder than case 5").

d) Personal criteria (e.g. "I don't like either of them ...”; "they are both immature"; "in both cases the problem began after their marriage"; "in both cases they had the same style of life").

2) The participants used different criteria to decide on similarities between the same sets of cases.

3) The criteria which psychiatrists used to explain similarities could be divided into two categories: formal/nonformal criteria and subtle/general criteria. a. Formal/nonformal criteria. For the purpose of this study, formal criteria were those criteria found in the literature that the subjects used for their decisions on the similarity between cases. These criteria included personality disorder categories; the categorization of traits; and rules describing the personality disorder, the traits and the axis. Examples from the interviews are as follows:

"They both have a borderline personality disorder, while the other case is narcissistic."

"In this pair, axis 1 is dominant, while in the other case axis 2 is dominant."

"There is meaning to the relationship between the patient and her psychiatrist.” 


\section{H. ESHACH}

Table 3.

Classes of differences between diagnoses.

\begin{tabular}{|c|c|}
\hline $\begin{array}{l}\text { Classes of differences } \\
\text { between diagnoses }\end{array}$ & \\
\hline $\begin{array}{l}\text { Identification of personality } \\
\text { disorders }\end{array}$ & In four cases (45\%), at least two participants did not identify a personality disorder. \\
\hline $\begin{array}{l}\text { Different diagnoses of } \\
\text { personality disorders }\end{array}$ & $\begin{array}{l}\text { Psychiatrists diagnosed differently the same cases. Examples: } \\
\text { 1) Case } 3 \text { was diagnosed by three participants (33\%) as narcissistic, while three other participants identified the case } \\
\text { as borderline personality disorder. } \\
\text { 2) Diagnoses for case 6: } \\
\text { a) Four participants did not identify any personality disorder. } \\
\text { b) One participant identified dependent traits. } \\
\text { c) Two participants identified dependent personality. } \\
\text { d) One participant identified schizoid personality disorder. } \\
\text { e) One participant identified narcissistic personality disorder. }\end{array}$ \\
\hline $\begin{array}{l}\text { Severity of personality } \\
\text { disorder }\end{array}$ & $\begin{array}{l}\text { In some cases there were differences in the severity attributed to the disorder. While some participants identify } \\
\text { personality disorders in a case, others identified only personality disorder traits. }\end{array}$ \\
\hline $\begin{array}{l}\text { Number of personality disorders } \\
\text { attributed to each patient }\end{array}$ & $\begin{array}{l}\text { For instance, in case } 7 \text {, four participants ( } 45 \%) \text { identified only narcissistic personality disorder. One participant } \\
\text { identified narcissistic personality disorder with obsessive-compulsive disorder. Three participants identified } \\
\text { narcissistic, dependent, and obsessive-compulsive personality disorders. }\end{array}$ \\
\hline
\end{tabular}

Nonformal criteria were those that were not found in the literature or occurred when personal meaning was given to formal criteria. Examples from the interviews are:

"This is his first admission in the hospital."

“They didn't achieve anything in life.”

"Only her economic status is important for her."

"Problems began after marriage."

"He is cold. Doesn't express feelings."

"They both make me nervous. I don't like them."

From these results we can conclude that psychiatrists use both formal and nonformal criteria to determine similarity between cases. In some cases the nonformal criteria had more weight in making the similarity decisions, while in other cases it carried less weight. The following examples will clarify this point:

Example 1: When participant 6 was provided with cases 2, 5, and 8 , he identified cases 5 and 8 as similar because "both have a gray personality and style, while case 2 is much more colorful." However, his main diagnosis for both cases 2 and 5 was narcissistic personality disorder, while he diagnosed case 8 as obsessive-compulsive disorder. Use of DSM-IV diagnostic criteria would lead to the decision that cases 2 and 5 are similar.

Example 2: When participant 3 was provided with cases 2, 3, and 5 , she identified cases 3 and 5 as similar because "both have a need for attention. Case 2 also needs attention, but he is colder; he doesn't express affection”. The basis for similarity was nonformal, by an idiosyncratic criterion. Moreover, she diagnosed case 2 as borderline and narcissistic personality disorders, case 3 as borderline and dependent personality disorders, and case 5 as narcissistic. Therefore, if the DSM-IV criteria had been the basis for her similarity decisions, it would be unlikely that she would have chosen cases 3 and 5, to whom she in fact gave different diagnoses. It would be more reasonable to determine cases 2 and 3 as similar, since they both suffered from borderline personality disorder. This demonstrates that idiosyncratic/nonformal criteria were more heavily weighted in this comparison.

b. General/subtle criteria. The results indicated that the participants used both general and subtle criteria. General criteria are those that require a rough level of diagnosis. For instance, personality disorder is a general criterion, whereas one specific rule appearing in the DSM-IV under that personality disorder category is a more subtle criterion. Examples from the interviews are:

\section{General criteria:}

"They are both borderline, while the other case is narcissistic."

"They are both from the same age range."

"They are both women."

\section{Subtle criteria:}

"He doesn't need to be in relationships with others."

"She hurt herself, feels emptiness."

"There are extreme fluctuations in their mood."

Another example of using subtle criteria was when the same diagnoses were given to three cases, but one was determined to be dissimilar to the other two, e.g., because "she is more stable". Here the severity attributed to the case required subtle criteria.

We therefore found no preference for the use of general over subtle criteria.

4) It was found that heuristics impacted on the criteria by which the participants determined similarities.

Heuristics are mental shortcuts, "rules of thumb", which do not guarantee a solution to the problem, but more often than not do succeed and save a lot of time and effort in the process (Eysenck \& Keane, 1995). Heuristics, which are commonly used in decision making, may lead to faulty reasoning or conclusions (Elstein, 1999). Representativeness and availability are examples of such heuristics (Kahneman, Slovic, \& Tversky, 1982).

The impact of "availability" heuristic

There are situations in which people are prone to overestimate the frequencies of easily recalled events (Elstein, 1999; Kahneman, Slovic, \& Tversky, 1982). This judgmental heuristic is called availability. Example from the interviews:

While dealing with case 2, participant 9 interpreted the details of that case and made the diagnosis in a very unique way. She was the only participant who diagnosed this case as psychotic, and she argued that he did not suffer from a personality disorder. Here are some justifications that she gave: 
"He has thoughts that he is a prophet, that he has fire in his bones. He always murmurs. He believes that if he does something, he will prevent things from happening. His ideas are not coherent ... It seems that the things in the interview are fragments, and the only connection between the different parts of the interview is that they are successive...It seems as if he is suffering from schizophrenia, though it is early to decide."

It was found that a special program dealing with many psychotic cases, in which one of the participants had participated for eight months prior to this study, had an impact on the diagnoses she gave and the similarity criteria she used. The cases the subject had dealt with prior to this study were easily brought to mind. As a result, her decisions were significantly based on these cases.

The impact of the "representativeness" heuristic

When deciding on the probability that object A belongs to class B, people typically rely on the "representativeness" heuristic, in which probabilities are evaluated by the degree to which $\mathrm{A}$ is representative of $\mathrm{B}$, that is, by the degree to which A resembles B (Kahneman, Slovic, \& Tversky, 1982).

For example, when participant 3 was provided with cases 3 , 5 , and 7 , she identified cases 5 and 7 as similar because “... nurse and physician [case 5 was a physician and case 7 was a nurse], this combination is achieving, persistence in work, high functional level, consistent ..."

Participant 3 had a mental picture of people who work in medical occupations. Therefore, it might have been that she felt a high probability that cases 5 and 7 belonged to this group. This heuristic therefore influenced her decisions on similarity.

5) Similarity process involves the search for local similarities.

While deciding on similarities between cases, psychiatrists focus only on part of the details of each case. The following example clarifies this point:

When provided with the cases 3, 5, and 7, participant 6 decided that cases " 5 and 7 are similar because they are both narcissistic. There is something obsessive in both cases. There is a failure in relating to their kids". When provided with the cases 5,7 , and 9 , the participant determined that 7 and 9 are similar because they are both "extravagant, dramatic, and dealing with emotions" (as opposed to 5 and 7). In another situation the participant noted "case 9 is similar to cases 2 and 4 because in all those cases there are changes in mood, which are expressed in their willingness to die. In both cases they harm themselves". According to this participant those are not characteristics of case 7 . For each comparison the participant focused on different characteristics of each case.

6) In $85 \%$ of the three-case sets, more than half of the subjects chose the same two cases as similar. Moreover, in $65 \%$ of the case sets, two thirds of the participants chose the same pair of cases. However, the explanations given to make these choices tended to be different, i.e., subjects tended to identify the same cases as similar, but gave different explanations.

\section{Discussion}

\section{Use of Idiosyncratic Personal Knowledge}

This research aimed at identifying the criteria by which psychiatrists decide similarities between personality disorders. Findings indicate that criteria consisted of nonformal and per- sonal knowledge. Moreover, sometimes these nonformal/personal criteria contradicted the diagnoses they identified. This result lends support to the important role of personal knowledge in reasoning which challenge the RBR models. RBR models emphasize on the importance of abstract information in problem solving and ignore the value of knowledge of a specific event and specific experiences (Cohen, 1996). The personal knowledge point of view, on the other hand, sees in knowledge of specific episodes a key to successful problem solving. Personal knowledge is defined as the unique frame of reference and knowledge of self, is central to the individual's sense of self (Higgs \& Titchen, 1995), and is a result of the individual's personal experiences (Butt, Raymond, \& Yamaguishi, 1982). Much of the knowledge a practitioner uses in problem solving and making clinical judgments is tacit and individual (Polanyi, 1958; Carroll, 1988). In recent years, there has been increasing concern about the growing gap between research-based knowledge taught in professional schools and the practical knowledge and actual competencies required of practitioners in the field (Schon, 1987). The author argues that in order to deal with the crisis in professional knowledge, we need to recognize that outstanding practitioners do not have more professional knowledge, but more “wisdom”, “talent”, “intuition”, or "artistry". By finding those personal criteria by which the psychiatrists in this study identified similarities may contribute to decreasing the gap that Schon warn us from.

\section{Local-Based Similarities Decisions}

Other result of this study is that psychiatrists' decisions regarding similarities between cases were based only on part of the details of each case. This result was also found in their diagnoses processes. Psychiatrists focused on only part of the evidence and did not take into consideration all the information described in those cases. It is my understanding that they searched for local coherence rather than a global coherence. An underlining idea of RBR is that the problem solver, by chaining together all the relevant domain's rules, and therefore consider all the information, is looking for global rather than local coherence.

\section{Use of Heuristics}

It was found that heuristics impacted on the criteria by which the participants determined similarities. Both representativeness and availability heuristic are similar-based as it depends on a memory retrieval process that in turn depends on the similarity between an encoded event and retrieval cues (Sloman \& Rips, 1998). Thus, it is not surprising that it characterize the psychiatrists who were confronted with a similarity task.

In $85 \%$ of the three-case sets, more than half of the subjects chose the same two cases as similar. Moreover, in $65 \%$ of the case sets, two thirds of the participants chose the same pair of cases. However, the explanations given to make these choices tended to be different, i.e., subjects tended to identify the same cases as similar, but gave different explanations.

\section{Application to Teaching}

One problem of today's teaching is the growing gap between research-based knowledge and actual competencies required of practitioners in the field (Eshach \& Bitterman, 2002). Psychiatrists are not always aware of their own personal knowledge 
and therefore are not always aware of their own as well as of other psychiatrists' criteria. These primary criteria have an impact on decision-making processes, which in most cases are based on similarity decisions. In addition, CBR might lead to faulty decisions. For instance, one might be tempted to use an old case blindly, relying on previous experience without validating it in the new situation (Kolodner, 1993). One strategy to minimize such a cognitive bias is to call these processes to the attention of the physician and medical educator, in the hope that when people are aware of these tendencies, they will take steps to overcome them. Therefore, educators should take such processes into account when they design learning environments. The present study provides many examples of criteria used in the comparison process and thus might be useful as a teaching aid. The results of this research may assist psychiatrists to be aware of their own and others' idiosyncratic criteria. This might also decrease the gap between book knowledge and the personal/practical experience of physicians, a concern that was expressed by Schon (1987). In other words, researchers should make efforts to make the implicit personal/practical experience of physicians more explicit. Educators, on their turn, should "use" explicit teaching - which refers to teaching that focuses on explicit awareness (mediated by verbal interactions) of types of cognitive procedures (i.e. strategies) being used in specific instances (Zohar \& Peled, 2007; Zohar \& Ben David, 2008)to teach those, yet, tacit personal cognitive procedures. This research could be expanded into other domains that rely on similarity diagnosis.

\section{Acknowledgements}

The author would like to thank the psychiatrists who participated in the study and Miss Ruth Singer for editing the manuscript.

\section{REFERENCES}

American Psychiatric Association (APA) (1994). Diagnostic and statistical manual of mental disorders (4th ed.). Washington, DC: APA.

BarOn, E. (1993). Locally coherent views: Toward a unifying theory of mental capacity and local coherence. Unpublished manuscript.

Barrows, H. S., \& Feltovich, P. J. (1987). The clinical reasoning process. Medical Education, 21, 86-91. doi:10.1111/j.1365-2923.1987.tb00671.x

Boshuizen, H. P. A., \& Schmidt, H. G. (1995). The development of clinical reasoning expertise. In J. Higgs, \& M. Jones (Eds.), Clinical reasoning in the health professions. Oxford: Butterworth-Heinemann Ltd.

Butt, R., Raymond, D., \& Yamaguishi, L. (1982). Autobiographic praxis: studying the formation of teachers' knowledge. Journal of Curriculum Theorizing, 7, 87-164.

Carroll, E. (1988). The role of tacit knowledge in problem solving in the clinical setting. Nurse Education Today, 8, 140-147. doi:10.1016/0260-6917(88)90031-7

Cohen, G. (1996). Memory in the real world (2nd ed.). Hove: Psychology Press.

Elstein, A. S. (1999) Heuristics and biases: Selected errors in clinical reasoning. Academic Medicine, 74, 791-794. doi:10.1097/00001888-199907000-00012

Eshach, H., \& Bitterman, H. (2002). From case-based reasoning to problem-based learning. Academic Medicine, 78, 491-496. doi:10.1097/00001888-200305000-00011

Eysenck, M. W., \& Keane, T. M. (1995). Cognitive psychology: A student's handbook (3rd ed.). Hove: Psychology Press.

Goldstone, R. L. (1994). The role of similarity in categorization: Pro- viding a groundwork. Cognition, 52, 125-157. doi:10.1016/0010-0277(94)90065-5

Goodman, N. (1972). Problems and projects. New York: Bobbs-Merrill.

Guba, E. G., \& Lincoln, Y. S. (1989). Fourth generation evaluation. Beverly Hills, CA: Sage Publications.

Higgs, J., \& Jones, M. (1995). Clinical reasoning. In J. Higgs, \& M. Jones (Eds.), Clinical reasoning in the health professions. Oxford: Butterworth Heinemann Ltd.

Higgs, J., \& Titchen, A. (1995). Propositional, professional and personal knowledge in clinical reasoning. In J. Higgs, \& M. Jones (Eds.), Clinical reasoning in the health professions. Oxford: ButterworthHeinemann Ltd.

Kahneman, D., Slovic, P., \& Tversky, A. (1982). Judgment under uncertainty: Heuristics and biases. Cambridge: Cambridge University Press. doi:10.1017/CBO9780511809477

Kaplan, H. I., \& Sadock, B. J. (1996). Concise textbook of clinical psychiatry. Philadelphia, PA: Lippincott, Williams \& Wilkins.

Kassirer, J. P., \& Kopelman, R. I. (1991). Learning clinical reasoning. Baltimore, MD: Williams \& Wilkins.

Kelly, G. A. (1955a). The psychology of personal constructs (Vol. 1: A theory of personality). New York: W.W. Norton \& Co.

Kelly, G. A. (1955b). The psychology of personal constructs (Vol. 2: Clinical diagnosis and psychotherapy). New York: W.W. Norton \& Co.

Kolodner, J. (1993). Case-based reasoning. San Mateo, CA: Morgan Kaufmann Publishers.

Kolodny, J. A. (1994) Memory processes in classification learning: An investigation of amnesic performance in categorization of dot patterns and artistic styles. Psychological Science, 5, 164-169. doi:10.1111/j.1467-9280.1994.tb00654.x

Leake, D. B. (1996). CBR in context: The present and future. In D. B. Leake (Ed.), Case-based reasoning: Experiences, lessons, \& future directions. Menlo Park, CA/Cambridge, MA: AAAI Press/MIT Press.

Morey, L.C. (1998). Personality diagnosis and personality disorders. In R. Hogan, J. Johnson, \& S. Briggs (Eds.), Handbook of personality psychology. San Diego, CA: Academic Press.

Mostow, J. (1983). Machine transformation of advice into a heuristic search procedure. In R. S. Michalski, J. G. Carbonell, \& T. M. Mitchell (Eds.), Machine learning: An artificial intelligence approach: Vol. 1. Los Altos, CA: Kaufmann. Norman, G. R., Coblentz, C. L., Brooks, L. R., \& Babcock, C. J. (1992). Expertise in visual diagnosis: A review of the literature. Academic Medicine, 67, S78-S83.

Patton, M. Q. (1990). Qualitative evaluation and research methods (2nd ed.). Newbury Park, CA: Sage Publications.

Polanyi, M. (1958). Personal knowledge: Towards a post-critical philosophy. London: Routledge \& Kegan Paul.

Rissland, E. L., \& Skalak, D. B. (1991). CABARET: Rule interpretation in a hybrid architecture. International Journal of Man-Machine Studies, 34, 839-887. doi:10.1016/0020-7373(91)90013-W

Rumelhart, D. E. (1989). Toward a microstructural account of human reasoning. In S. Vosniadou, \& A. Ortony (Eds.), Similarity and analogical reasoning. New York: Cambridge University Press. doi:10.1017/CBO9780511529863.014

Schon, D. A. (1987). Educating the reflective practitioner: Toward a new design for teaching and learning in the professions. San Francisco, CA: Jossey-Bass.

Sloman, S. A., \& Rips, J. L. (1998) Similarity as an explanatory construct. In A. S. Sloman, \& L. J. Rips (Eds.), Similarities and symbols in human thinking. Cambridge, MA: MIT Press.

Strauss, A. L. (1987). Qualitative analysis for social scientists. New York: Cambridge University Press. doi:10.1017/CBO9780511557842

Vosniadou, S., \& Ortony, A. (1989). Similarity and analogical reasoning. New York: Cambridge University Press. doi:10.1017/CBO9780511529863

Voss, J. F., \& Post T. A. (1988). On the solving of ill-structured problems. In M. T. H. Chi, R. Glaser, \& M. J. Farr (Eds.), The nature of expertise. Hillsdale, NJ: Lawrence Erlbaum Associates.

Williams, S. M. (1992). Putting case-based instruction into context: 


\section{H. ESHACH}

Examples from legal and medical education. Journal of the Learning Sciences, 2, 367-427. doi:10.1207/s15327809jls0204_2

Zohar, A., \& Peled, B. (2008). The effects of explicit teaching of metastrategic knowledge on low- and high-achieving students. Learning and Instruction, 18, 337-353. doi:10.1016/j.learninstruc.2007.07.001 Zohar, A., \& Ben David, A. (2008). Explicit teaching of meta-strategic knowledge in authentic classroom situations. Metacognitive Learning, 4, 59-82. doi:10.1007/s11409-007-9019-4 